\section{BRAZIULIAN JOURNAL}

OF MEDICAL AND BIOLOGICAL RLSH.ARCH

www.bjournal.com.br
ISSN 0100-879X

Volume 43 (01) 1-123 January 2010

BIOMEDICAL SCIENCES

AND

CLINICAL INVESTIGATION

Braz J Med Biol Res, J anuary 2010, Volume 43(1) 17-24

A DNA enzyme targeting Egr-1 inhibits rat vascular smooth muscle cell proliferation by down-regulation of cyclin D1 and TGF- $\beta 1$

Y. Wu, W. Han and G.-N. Liu

The Brazilian Journal of Medical and Biological Research is partially financed by
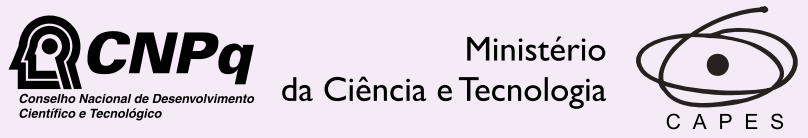

Ministério da Educação

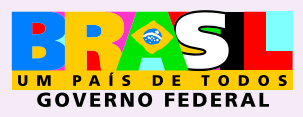

Institutional S ponsors 


\title{
A DNA enzyme targeting Egr-1 inhibits rat vascular smooth muscle cell proliferation by down-regulation of cyclin D1 and TGF- $\beta 1$
}

\author{
Y. Wu, W. Han and G.-N. Liu
}

Department of Cardiology, The First Affiliated Hospital of China Medical University, Shenyang, China

\begin{abstract}
We have demonstrated that a synthetic DNA enzyme targeting early growth response factor-1 (Egr-1) can inhibit neointimal hyperplasia following vascular injury. However, the detailed mechanism of this inhibition is not known. Thus, the objective of the present study was to further investigate potential inhibitory mechanisms. Catalytic DNA (ED5) and scrambled control DNA enzyme (ED5SCR) were synthesized and transfected into primary cultures of rat vascular smooth muscle cells (VSMCs). VSMC proliferation and DNA synthesis were analyzed by the MTT method and BrdU staining, respectively. Egr-1, TGF- $\beta 1$, p53, p21, Bax, and cyclin D1 expression was detected by RT-PCR and Western blot. Apoptosis and cell cycle assays were performed by FACS. Green fluorescence could be seen localized in the cytoplasm of $70.6 \pm 1.52$ and $72 \pm 2.73 \%$ VSMCs 24 $\mathrm{h}$ after transfection of FITC-labeled ED5 and ED5SCR, respectively. We found that transfection with ED5 significantly inhibited cultured VSMC proliferation in vitro after 24,48 , and $72 \mathrm{~h}$ of serum stimulation, and also effectively decreased the uptake of BrdU by VSMC. ED5 specifically reduced serum-induced Egr-1 expression in VSMCs, further down-regulated the expression of cyclin D1 and TGF- $\beta 1$, and arrested the cells at $\mathrm{G}_{0} / \mathrm{G}_{1}$, inhibiting entry into the S phase. FACS analysis indicated that there was no significant difference in the rate of apoptosis between ED5- and ED5SCR-transfected cells. Thus, ED5 can specifically inhibit Egr-1 expression, and probably inhibits VSMC proliferation by down-regulating the expressions of cyclin D1 and TGF- $\beta 1$. However, ED5 has no effect on VSMC apoptosis.
\end{abstract}

Key words: DNA enzyme; Egr-1; VSMC; Proliferation; Apoptosis

\section{Introduction}

Although atherogenesis, percutaneous transluminal coronary angioplasty, and the subsequent anastomotic restenosis of the vasculature is a complicated pathological process involving multiple factors (1-3), the over-production of extracellular matrix by smooth muscle cells of the injured vessel, their hyperproliferation and their migration to the intima play a key role in lesion formation (4). Local endogenous early growth response factor-1 (Egr-1) is rapidly expressed and activated following vascular injury (5). Egr-1, an immediate-early gene product and zinc finger transcription factor, regulates the expression of multiple proliferation-associated genes (6,7), and Egr-1 levels closely correlate with cell proliferation (8). Deoxyribozyme (DNA enzyme, DRz) is a small single-stranded DNA fragment with enzymatic activity that cleaves specific RNA strands thereby regulating protein expression. In a previous study, we synthesized a specific DRz targeting rat Egr-1 mRNA (DNA enzyme/10-23 DRz, ED5), and transfected it into the rat carotid following balloon injury. We found that ED5 could inhibit neointimal hyperplasia (9) although the detailed mechanism underlying the inhibition was unclear. In the present study, we further analyzed the ED5-transfected vascular smooth muscle cells (VSMCs) by measuring the levels of Egr-1, TGF- $\beta 1$, p53, p21, Bax, and cyclin D1 expression, changes in the cell cycle, apoptosis, cell proliferation, and DNA synthesis.

\section{Material and Methods}

\section{VSMC isolation and primary culture}

Rat primary aortic VSMCs were isolated as described previously (10). Briefly, Wistar rats (120 g, purchased from the Experimental Center, China Medical University) were sacrificed with excess anesthesia. The intima was peeled off from the aorta and the media stripped away. The medial layer was cut into approximately $1-\mathrm{mm}^{2}$ squares, which were

Correspondence: G.-N. Liu, Department of Cardiology, The First Affiliated Hospital of China Medical University, Shenyang 110001, China. Fax: +86-24-2328-1638. E-mail: guinanliu@hotmail.com

Received August 12, 2009. Accepted November 10, 2009. Available online November 23, 2009. Published January 11, 2010. 
transferred to a 35- $\mathrm{mm}$ plate and barely covered with DMEM supplemented with $20 \%$ FBS (Gibco-BRL, USA). The tissue blocks were cultured at $37^{\circ} \mathrm{C}$ in a humid atmosphere of $5 \%$ $\mathrm{CO}_{2}$. After 2 weeks, cells that had migrated onto the tissue culture dish were collected by trypsinization and subcultured successively; cells were used from the fourth to the eighth passage. Culture homogeneity was confirmed by staining for smooth muscle actin and was confirmed when staining exceeded $98 \%$ (Figure 1).

\section{ED5 synthesis and transfection}

The catalytic DNA, ED5, and scrambled control DNA enzyme, ED5SCR, were synthesized by Takara (China). The sequences were as follows: ED5 5'-CCGCTGCCAGG CTAGCTACAACGACCCGGACGT-3'; ED5SCR 5'-GCC AGCCGCGGCTAGCTACAACGATGGCTCCAC-3'. The underlined regions at both ends are the oligonucleotide recognition sequences and the middle sequences represent the conserved catalytic zone. The 5' and 3' termini of the oligonucleotides were protected from exonucleases by a phosphorothioate linkage. The 5' terminus was labeled with fluorescein isothiocyanate (FITC) to identify gene distribution under fluorescence microscopy. VSMCs at $70 \%$ confluence were cultured in serum-free medium for $30 \mathrm{~h}$ and then transfected with $0.1 \mu \mathrm{M}$ ED5 or ED5SCR using FuGENE6 in the dark for $18 \mathrm{~h}$. The medium was then replaced with DMEM supplemented with $10 \%$ FBS containing $0.1 \mu \mathrm{M}$ ED5 or ED5SCR using FuGENE6 and incubated for 24

Table 1. PCR primers used in the present study.

\begin{tabular}{|c|c|c|}
\hline & Primer sequence & Size \\
\hline \multicolumn{3}{|c|}{$5^{\prime} \rightarrow 3^{\prime}$} \\
\hline \multirow[t]{2}{*}{ Egr-1 } & CAGTCGTAGTGACCACCTTACCA & $449 \mathrm{bp}$ \\
\hline & AGGTTGCTGTCATGTCTGAAAGAC & \\
\hline \multirow[t]{2}{*}{ TGF- $\beta 1$} & CTGAACCAAGGAGACGGAATACA & $462 \mathrm{bp}$ \\
\hline & CAAAGCCTGCGGCACG & \\
\hline \multirow[t]{2}{*}{ p53 } & GTGGCCTCTGTCATCTTCCG & $292 \mathrm{bp}$ \\
\hline & CCGTCACCATCAGAGCAACG & \\
\hline \multirow[t]{2}{*}{ p21 } & TCCGATCCTGGTGATG & $442 \mathrm{bp}$ \\
\hline & TCTGTTAGGCTGGTCTGC & \\
\hline \multirow[t]{2}{*}{ Bax } & GACACCTGAGCTGACCTTGG & $311 \mathrm{bp}$ \\
\hline & GAGGAAGTCCAGTGTCCAC & \\
\hline \multirow[t]{2}{*}{ Cyclin D1 } & СTGACACCAАTCTССТСААCGAC & $409 \mathrm{bp}$ \\
\hline & GCGGCCAGGTTCCACTTGAGC & \\
\hline \multirow[t]{2}{*}{ GAPDH } & ACCACAGTCCATGCCATCAC & $452 \mathrm{bp}$ \\
\hline & TCCACCACCCTGTTGCTGTA & \\
\hline
\end{tabular}

GAPDH = internal control. $\mathrm{h}$. The medium was discarded and $2 \mathrm{~mL}$ PBS was added. Transfection efficiency was determined using an inverted fluorescent microscope (Olympus, Japan).

\section{MTT assay}

VSMC proliferation was assayed using a colorimetric (MTT) assay kit (Amersco, USA). Approximately 5000 cells/ well were plated onto a 96-well plate and incubated with $0.1 \mu \mathrm{M}$ ED5 or ED5SCR using FuGENE6 for various times. Four hours before the end of the incubation, $100 \mu \mathrm{g}$ MTT was added to each well. MTT was then removed and the cells were solubilized with $150 \mu \mathrm{L}$ dimethyl sulfoxide. The absorbance of each well was measured using a microculture plate reader at $490 \mathrm{~nm}$. The cell inhibition ratio (IR) was expressed using the following equation: IR = (absorbance in control - absorbance in treated groups / absorbance in control) $\times 100 \%$.

\section{Apoptosis and cell cycle assay}

Apoptosis was measured by staining cells with a combination of fluoresceinated (FITC) annexin $\mathrm{V}$ and propidium iodide $(\mathrm{PI})$ as described previously. Briefly, after transfection for $72 \mathrm{~h}$, the VSMCs were resuspended in $100 \mu \mathrm{L}$ binding buffer (140 mM NaCl, $2.5 \mathrm{mM} \mathrm{CaCl}_{2}, 10 \mathrm{mM}$ HEPES, pH 7.4). Next, $5 \mu \mathrm{L}$ annexin V-FITC and $10 \mu \mathrm{L} \mathrm{PI}(20 \mu \mathrm{g} / \mathrm{mL}$; Jingmei, China) were added and incubated for $15 \mathrm{~min}$ at room temperature in the dark. Data were acquired with a flow cytometer (Becton Dickinson, USA). PI-stained cells were analyzed with a FACSCalibur flow cytometer (Becton Dickinson) for cell cycle analysis. The cell proliferation index (CPI) was calculated using the following equation: $\mathrm{CPI}=$ $\left(\left(S+G_{2} / M\right) /\left(G_{0} / G_{1}+S+G_{2} / M\right)\right) \times 100 \%$.

\section{RT-PCR}

Total RNA was isolated using a Takara RNA PCR kit according to manufacturer instructions. The PCR primers were designed by Takara (China) and are shown in Table 1. GAPDH was amplified as an internal control. The amplification was performed with 30 cycles, which was the optimal condition for linearity and permitted semiquantitative analysis of signal strength (temperature profile: $93^{\circ} \mathrm{C}$ for $30 \mathrm{~s}, 55^{\circ} \mathrm{C}$ for $30 \mathrm{~s}, 72^{\circ} \mathrm{C}$ for $1 \mathrm{~min}$ ). PCR products were separated by $1.5 \%$ agarose gel electrophoresis and stained with DNAgreen (Bioteke Co., China). The target bands were analyzed densitometrically with a gel image analysis system (Chemi Imager 5500, Alpha Innotech, USA).

\section{Western blot analysis}

Aliquots of cell lysates containing $50 \mu \mathrm{g}$ protein were separated by $10 \%$ SDS-polyacrylamide gel electrophoresis and transferred to nitrocellulose filters. The filters were blocked with TBS-T buffer containing $5 \%$ skim milk, incubated with antibodies (1:300) against Egr-1, TGF- $\beta 1$, p53, p21, Bax, cyclin D1 (Santa Cruz Biotechnology, USA) and $\beta$-actin (Sigma, USA) overnight, followed by the addition 
of a horseradish peroxidase-linked anti-mouse or rabbit IgG (Maixin Biological Company, China) and binding was visualized following incubation with a DAB solution (Maixin Biological Company). $\beta$-actin expression was used as an internal control to normalize protein content. Bands were scanned using a GS-800 Calibrated Densitometer (BioRad, USA) and results were quantified using Quantity One software (Bio-Rad).

\section{Bromodeoxyuridine (BrdU) incorporation}

To measure BrdU incorporation, cells were seeded on coverslips and, at the indicated times, $10 \mu \mathrm{M}$ BrdU (Sigma) was added to the medium for $24 \mathrm{~h}$. Cells were then harvested and fixed in ice-cold $75 \%$ ethanol, treated with $2 \mathrm{~N} \mathrm{HCl}$, neutralized with $0.1 \mathrm{M}$ borax, washed with PBS containing $0.05 \%$ bovine serum albumin, and incubated with anti-BrdU antibody (Sigma). BrdU incorporated into the cell nuclei was visualized by the avidin-biotin-peroxidase complex method using $\mathrm{DAB}$. The signal intensity within a given area was quantified from digital images using Metamorph software (Universal Imaging Corporation, USA).

\section{Statistical analyses}

Experiments were repeated three to five times. Unless otherwise indicated, data are reported as means $\pm S D$. Data were analyzed by one-way analysis of variance followed by the least significant difference (LSD) method for multiple comparisons. Differences were considered to be significant if $P<0.05$. All analyses were performed using the SPSS 13.0 software.

\section{Results}

\section{Transfection efficiency}

The FITC-labeled ED5 and ED5SCR were readily detectable with the fluorescence microscope apparently within the cytoplasm and, to a lesser extent, within the nucleus as a result of endocytosis. Green fluorescence could be seen localized in the cytoplasm of $70.6 \pm 1.52$ and $72 \pm 2.73 \%$ VSMCs $24 \mathrm{~h}$ after transfection of FITC-labeled ED5 and ED5SCR, respectively.

\section{ED5 inhibits Egr-1 and TGF- $\beta 1$ expression}

Under serum-free conditions, very little Egr-1 and TGF- $\beta 1$ mRNA expression and no Egr-1 protein expression were detected in VSMCs (Figures $2 \mathrm{~A}$ and $3 \mathrm{~A}$ ). After $1 \mathrm{~h}$ of serum stimulation, Egr-1 was expressed extensively and its levels began to decline after $4 \mathrm{~h}$ of serum stimulation. Egr$1 \mathrm{mRNA}$ and protein expression levels in ED5-transfected cells were significantly lower than in either ED5SCRtransfected or control cells at all times $(P<0.05$; Figures $2 \mathrm{~B}$ and $3 \mathrm{~B}$ ). After $1 \mathrm{~h}$ of serum stimulation, TGF- $\beta 1$ began to increase and peaked after $24 \mathrm{~h}$ of stimulation. TGF- $\beta 1$ mRNA and protein expression levels in ED5-transfected cells were significantly lower than in ED5SCR-transfected or control cells at all times $(P<0.05$; Figures $2 B$ and $3 B)$. Egr1 and TGF- $\beta 1$ expression levels did not differ significantly between ED5SCR-transfected and control cells.

\section{ED5 inhibits cell proliferation and DNA synthesis}

As shown in Figure 4, ED5-transfected cell proliferation was significantly inhibited compared to the proliferation of ED5SCR-transfected and control cells $(P<0.05)$. This inhibition occurred in a time-dependent manner. The rate of BrdU incorporation into ED5-transfected cells was also significantly decreased $(P<0.01$; Figure 5$)$. However, there was no significant difference in the degree of cell proliferation or DNA synthesis between ED5SCR-transfected and control cells.

\section{ED5 caused $G_{0} / G_{1}$ phase arrest by down-regulating cyclin D1}

Under serum-free conditions, $89.99 \pm 2.96 \%$ of VSMCs were at the $G_{0} / G_{1}$ stage, and only $1.62 \pm 0.11 \%$ were at the $\mathrm{S}$ stage. After $24 \mathrm{~h}$ of serum stimulation the proportion of cells in the $S$ stage was significantly increased to $13.16 \%$, and the proportion of cells in the $G_{0} / G_{1}$ stage was decreased to $81.84 \%$. However, after ED5 treatment, the cells in the $G_{0} / G_{1}$ stage were significantly increased and the cells at $S+G_{2} / M$ were significantly decreased. There was no difference between ED5SCR-transfected and control in cell cycle stage after any treatment (Table 2). The CPI

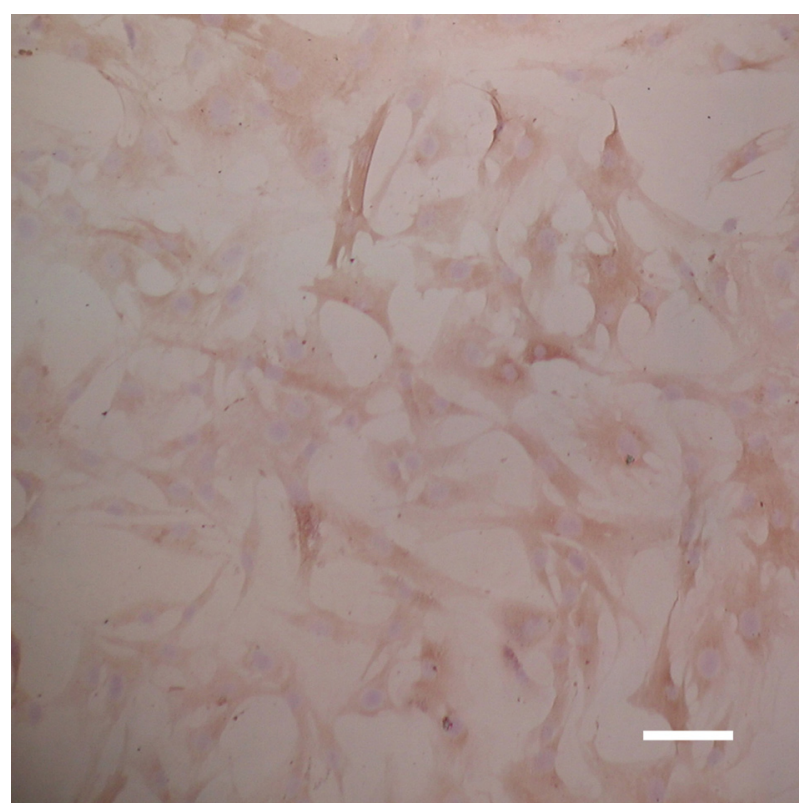

Figure 1. Immunochemical identification of vascular smooth muscle cells. The homogeneity of cultured cells was more than $98 \%$ as indicated by staining for smooth muscle actin using monoclonal rat-specific antibody obtained from Sigma (USA). Bar: $10 \mu \mathrm{m}$. 
was significantly lower in ED5-transfected cells compared to ED5SCR-transfected and control cells at all times. We found that both cyclin D1 mRNA and protein expression in ED5-transfected cells was significantly decreased as well (Figure 6). These results indicated that ED5 may downregulate cyclin D1 expression, arrest the cells at the $G_{0} / G_{1}$ phase, and block their entry into the $S$ phase.

\section{Apoptosis is not involved in ED5 inhibition}

FACS analysis indicated that there was no significantly difference in the rate of apoptosis between ED5-transfected cells, ED5SCR-transfected cells and control cells (Figure 7I). ED5 did not induce necrosis of VSMC. Under serumfree conditions, only low levels of p53, p21, and Bax mRNA expression, and no protein expression, were detected in VSMCs (Figure 7II,III). After $1 \mathrm{~h}$ of serum stimulation, p53, p21, and Bax mRNA expression began to increase and peaked at 24 h. p53 and p21 protein expression was increased, but Bax protein was not detected. There was no significant difference in p53, p21, and Bax levels between ED5-transfected cells, ED5SCR-transfected cells, and control cells.
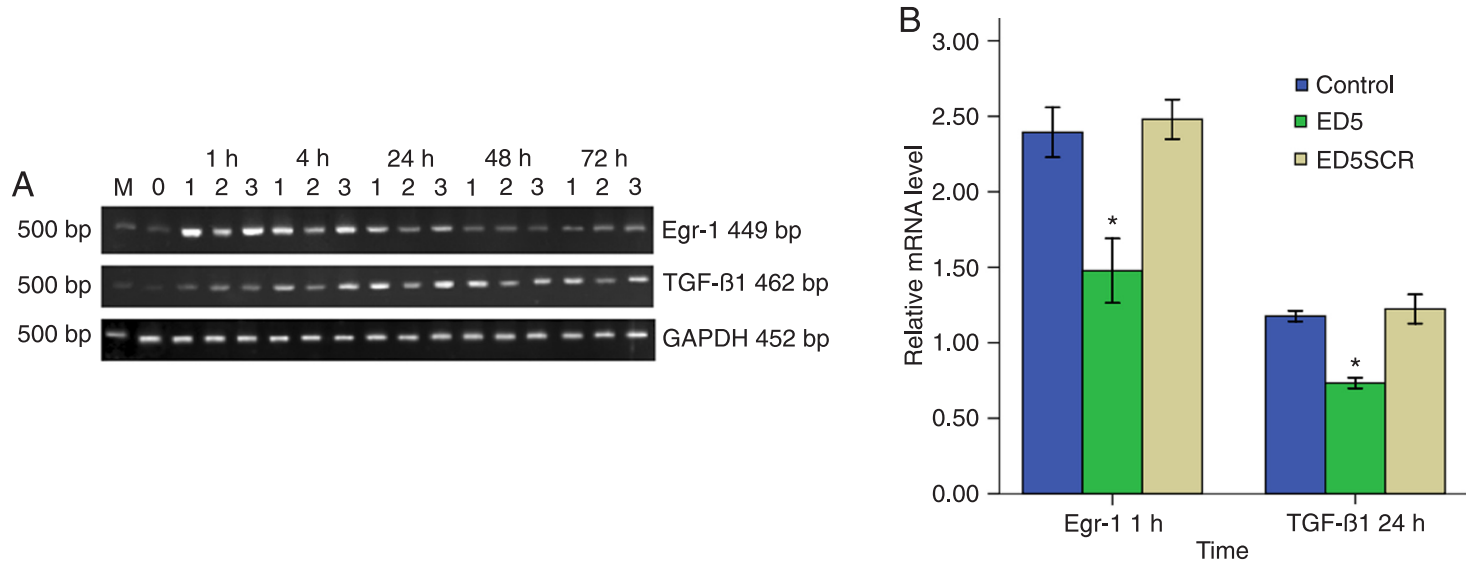

Figure 2. Representative expression of Egr-1 and TGF- $\beta 1$ mRNA in cultured vascular smooth muscle cells (VSMC) in each group. A, DNA marker (M); serum-free VSMCs (lane 0); normal VSMCs as control (lane 1); VSMCs transfected with ED5 (lane 2); VSMCs transfected with ED5SCR (lane 3). Expression of Egr-1 and TGF- $\beta 1$ mRNA was significantly inhibited following ED5 transfection. $B$, Quantitative data are shown in the graph. Comparison to normal VSMCs and ED5SCR-transfected cells showed that Egr-1 and TGF- $\beta 1$ mRNA expression in ED5-transfected cells was significantly inhibited. GADPH is the internal control. *P $<0.01$, compared to control and ED5SCR (one-way ANOVA).

A

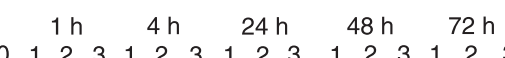
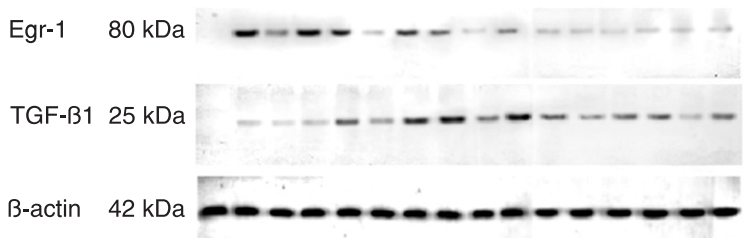

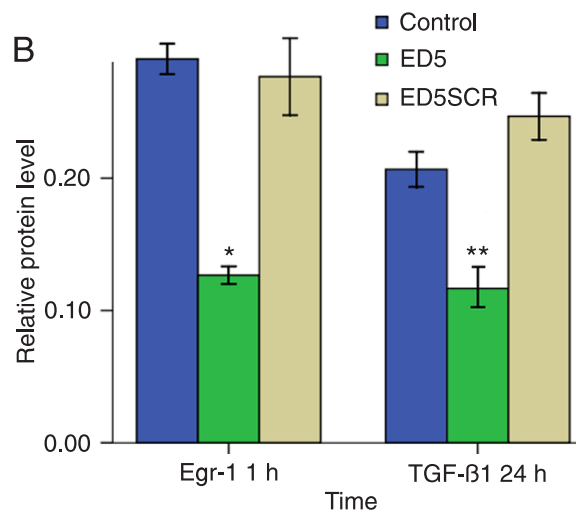

Figure 3. Time-lapse expression of Egr-1 and TGF- $\beta 1$ protein levels in cultured vascular smooth muscle cells (VSMC) in each group. A, DNA marker (M); serum-free VSMCs (lane 0); normal VSMCs as control (lane 1); VSMCs transfected with ED5 (lane 2); VSMCs transfected with ED5SCR (lane 3). The expression of Egr-1 and TGF- $\beta 1$ protein levels was significantly inhibited following ED5 transfection. B, Quantitative data are shown in the graph. Comparison to control and ED5SCR-transfected cells showed that Egr-1 and TGF- $\beta 1$ protein expression in ED5-transfected cells was significantly inhibited. $\beta$-actin is the internal control. ${ }^{*} \mathrm{P}<0.01$, ${ }^{* *} \mathrm{P}<0.05$, compared to control and ED5SCR (one-way ANOVA). 


\section{Discussion}

Transcription factors are DNA-binding proteins that can bind to a specific sequence of the gene promoter to regulate gene expression. Recent studies $(11,12)$ have found that some transcription factors can regulate the expression of several VSMC proliferation-associated genes, and thereby regulate VSMC proliferation. Egr-1 is a zinc finger transcription factor expressed at low basal levels or not expressed in normal vascular walls. However, following stimulation such as arterial injury, VSMCs and endothelial cell express Egr-1, which in turn promotes VSMC division, proliferation, and intimal hyperplasia $(13,14)$. Consequently, interfering with the expression of the Egr-1 transcription factor gene as a method to inhibit VSMC proliferation and reduce intimal hyperplasia may provide a novel treatment for restenosis.

10-23 DRz, a DNA enzyme obtained by in vitro target screening (15), successfully hydrolyzes the phosphodiester bond binding free purine and paired pyrimidine. Because its active center is composed of a non-variable sequence, the recognition sequence at the two ends can vary depending on the sequence of the target substrate RNA. This enzyme can then theoretically cut the AUG loci located in any RNA sequence. Our previous study (9) demonstrated the speci-

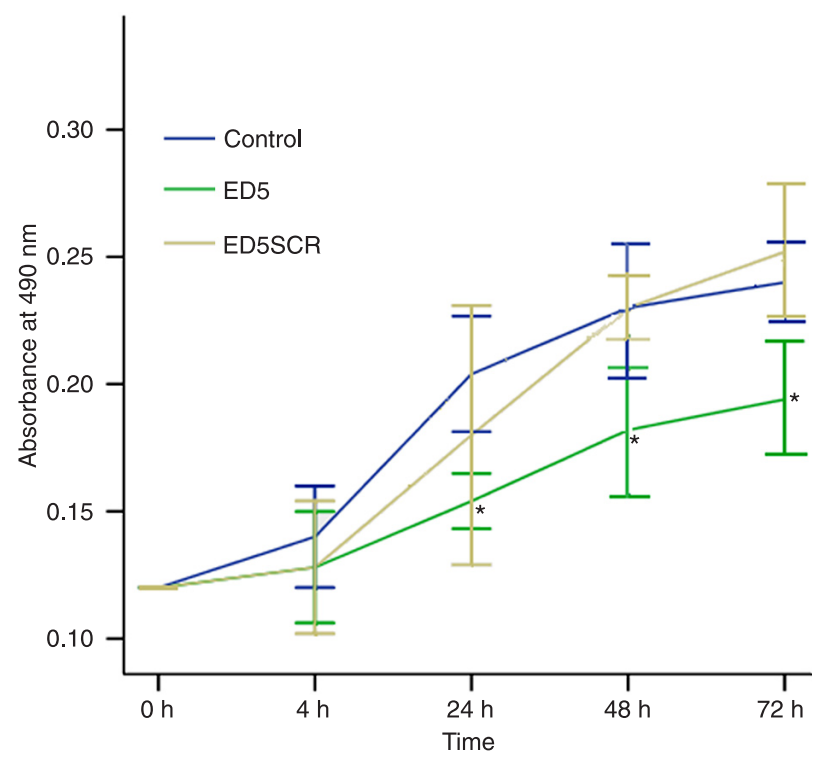

Figure 4. MTT cell proliferation assay. ED5-transfected cell proliferation was significantly inhibited following transfection for 24 , 48 , and $72 \mathrm{~h}$. The cell inhibition ratio (IR) was expressed using the following equation: $I R=$ (absorbance in control - absorbance in treated groups / absorbance in control) $\times 100 \%$. ${ }^{*} \mathrm{P}<0.05$, compared to control and ED5SCR (one-way ANOVA).
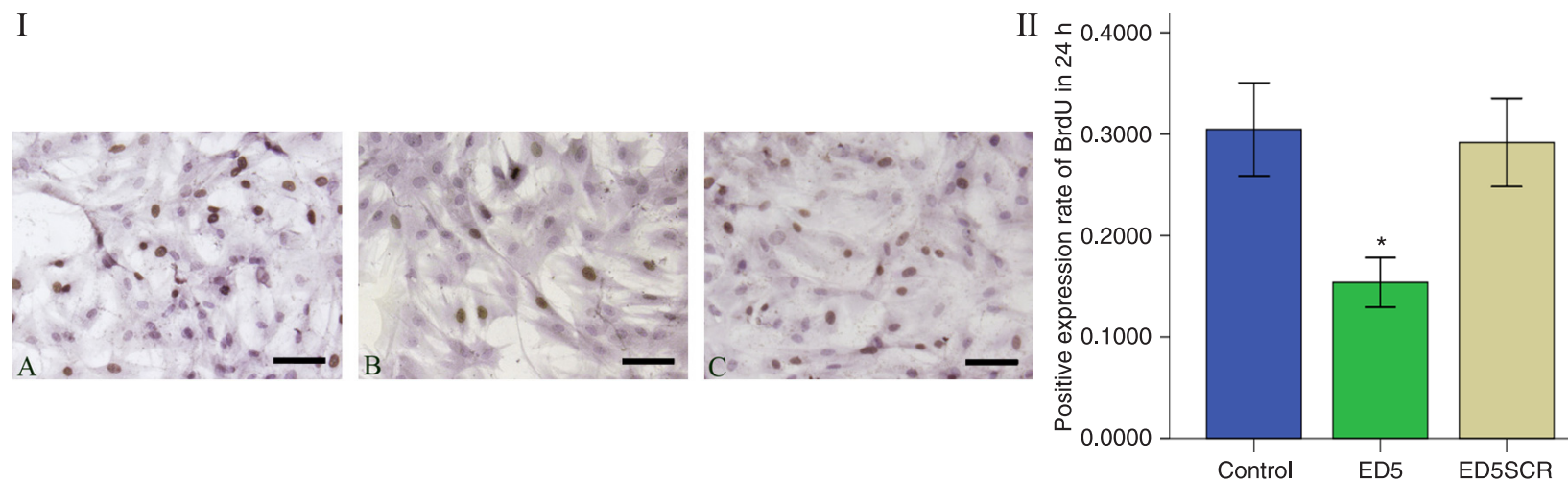

Figure 5. I, BrdU labeling of normal vascular smooth muscle cells (VSMC) as control (A), VSMCs transfected with ED5 (B), and VSMCs transfected with ED5SCR (C). DNA synthesis was significantly inhibited following ED5 transfection for $24 \mathrm{~h}$. Bars: $10 \mu \mathrm{m}$. II, Quantitative data are shown in the graph. Comparison to control and ED5SCR-transfected cells showed that the rate of BrdU incorporation in ED5-transfected cells was significantly decreased ( ${ }^{*} P<0.01$, one-way ANOVA).

Table 2. Effects of ED5 transfection on the cell cycle of vascular smooth muscle cells (VSMC).

\begin{tabular}{|c|c|c|c|c|c|c|c|c|c|}
\hline \multirow[t]{2}{*}{ Group } & \multicolumn{3}{|c|}{$24 \mathrm{~h}$} & \multicolumn{3}{|c|}{$48 \mathrm{~h}$} & \multicolumn{3}{|c|}{$72 \mathrm{~h}$} \\
\hline & $\mathrm{G}_{0} / \mathrm{G}_{1}$ & S & $\mathrm{G}_{2} / \mathrm{M}$ & $\mathrm{G}_{0} / \mathrm{G}_{1}$ & S & $\mathrm{G}_{2} / \mathrm{M}$ & $\mathrm{G}_{0} / \mathrm{G}_{1}$ & $S$ & $\mathrm{G}_{2} / \mathrm{M}$ \\
\hline Control & $81.84 \pm 1.20$ & $13.16 \pm 0.87$ & $5.00 \pm 0.44$ & $81.2 \pm 0.45$ & $14.22 \pm 0.73$ & $4.58 \pm 0.47$ & $81.17 \pm 1.68$ & $16.70 \pm 0.64$ & $2.13 \pm 0.05$ \\
\hline ED5 & $91.14 \pm 0.77^{*}$ & $4.19 \pm 0.23^{*}$ & $4.80 \pm 0.45$ & $93.9 \pm 0.08^{*}$ & $0.93 \pm 0.05^{*}$ & $5.15 \pm 0.14$ & $96.85 \pm 0.17^{*}$ & $0.28 \pm 0.01^{*}$ & $2.54 \pm 0.24$ \\
\hline ED5SCR & $81.80 \pm 0.62$ & $12.52 \pm 0.38$ & $5.67 \pm 0.28$ & $81.38 \pm 1.08$ & $13.86 \pm 0.06$ & $4.74 \pm 0.12$ & $81.25 \pm 0.02$ & $16.27 \pm 0.18$ & $2.48 \pm 0.20$ \\
\hline
\end{tabular}

Data are reported as means \pm SD of the percent of cells in each stage of the cell cycle. ${ }^{*} P<0.05$ compared to control and ED5SCRtransfected cells with same cycle stage (LSD test). 

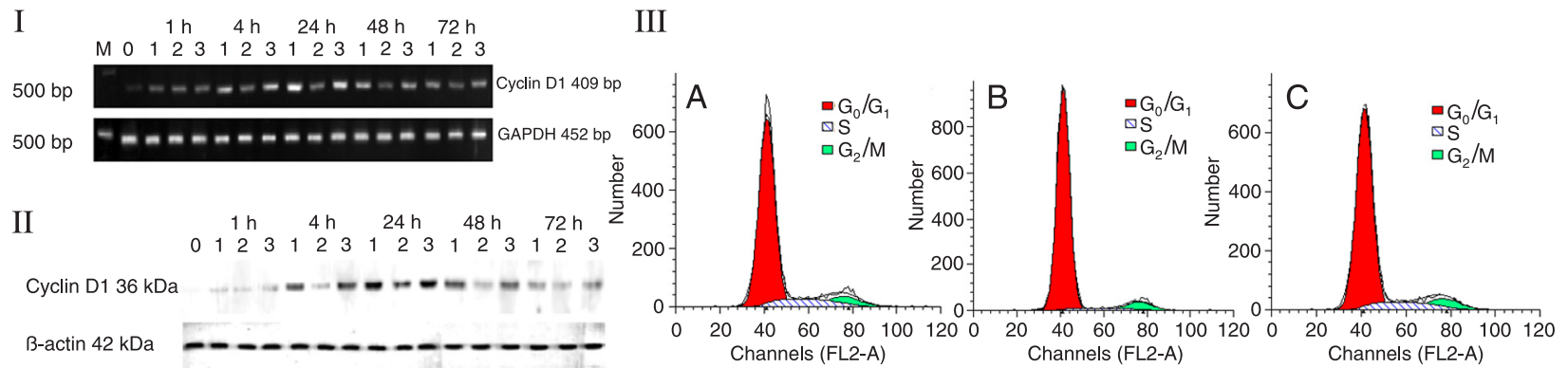

Figure 6. ED5 transfection induces $\mathrm{G}_{0} / \mathrm{G}_{1}$ arrest by down-regulating cyclin D1. ED5 (lane 2) treatment inhibited cyclin D1 mRNA (I) and protein (II) expression levels relative to the control (lane 1) and ED5SCR-transfected (lane 3) cells. The vascular smooth muscle cell (VSMC) cycle was arrested at the $\mathrm{G}_{0} / \mathrm{G}_{1}$ phase and entry into the $\mathrm{S}$ phase was blocked $48 \mathrm{~h}$ after $10 \%$ FBS stimulation as determined by FACS (III). A, Normal VSMCs as control; $B$, VSMCs transfected with ED5; $C$, VSMCs transfected with ED5SCR. GADPH and $\beta$-actin are internal controls.

I

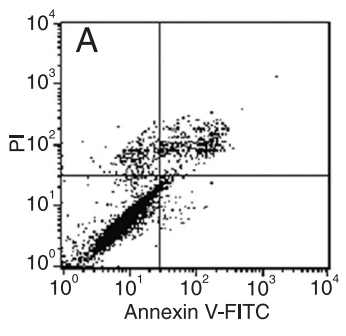

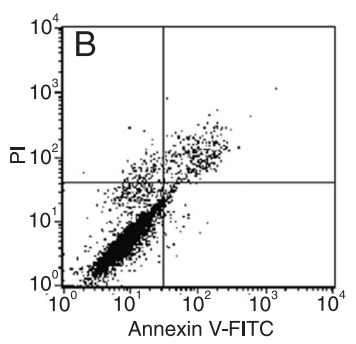

II $\quad \begin{array}{lllllll}1 \mathrm{~h} & 4 \mathrm{~h} & 24 \mathrm{~h} & 48 \mathrm{~h} & 72 \mathrm{~h} \\ 0 & 123 & 123 & 123 & 123 & 12 & 3\end{array}$

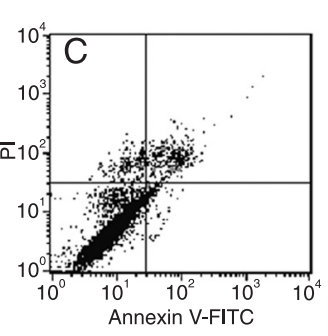

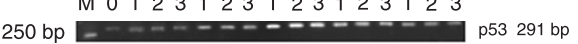
500 bp -----------------1 p21 442 bp $500 \mathrm{bp}$ -

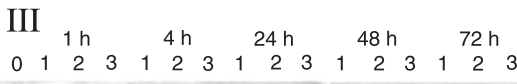
500 bp

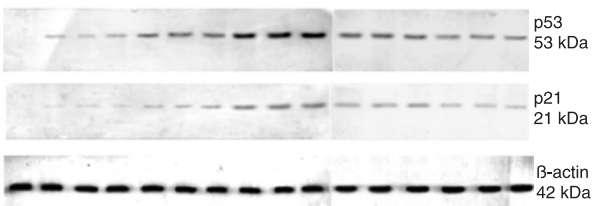

Figure 7. I, FACS analysis indicated that there was no significant difference in the rate of apoptosis between control cells (A), ED5transfected cells (B) and ED5SCR-transfected cells (C) after transfection for $72 \mathrm{~h}$. II, Under serum-free conditions (lane 0 ), only low levels of p53, p21, and Bax mRNA expression were observed. There was no significant difference in p53, p21, or Bax mRNA levels between control (lane 1), ED5-transfected (lane 2), and ED5SCR-transfected (lane 3) cells. III, Under serum-free conditions (lane 0), no protein expression was detected in VSMCs. There was no significant difference in p53 and p21 protein levels between control (lane 1), ED5-transfected (lane 2) and ED5SCR-transfected (lane 3) cells. GADPH and $\beta$-actin are internal controls.

ficity and efficacy of synthetic ED5 for inhibiting Egr-1 and reducing subsequent intimal hyperplasia. However, the exact mechanism of ED5 action and whether it is related to cell apoptosis was unclear. In the present study, a specific DNA enzyme targeting the mRNA of the transcription factor Egr-1 was synthesized to investigate a putative mechanism of rat VSMC proliferation and apoptosis.

MTT was first employed in our study to evaluate the transfection efficiency; we found that transfection with ED5 significantly inhibited cultured rat VSMC proliferation in vitro after 24,48 , and $72 \mathrm{~h}$ of serum stimulation. We also found that cells transfected with ED5 could effectively inhibit the uptake of BrdU by VSMC; specifically, the number of cells in the DNA synthesis phase decreased, whereas the control transfection ED5SCR showed no such effects.
These results indicate that ED5 likely affects entry into the cell cycle after specifically inhibiting Egr-1 expression. To explore this hypothesis, we employed FACS analysis, which revealed that, following transfection with ED5, the ratio of cells in the S phase and the cell proliferation index were markedly decreased, whereas the ratio of cells in the $\mathrm{G}_{0} /$ $\mathrm{G}_{1}$ phase was increased. ED5 transfection prevented FBSinduced progression to the $S$ phase from the $G_{0} / G_{1}$ phase. Control transfections did not show this pattern. Therefore, ED5 transfection not only affected cell cycle regulation, but specifically influenced the $\mathrm{G}_{1} / \mathrm{S}$ phase transition.

To confirm this hypothesis, we further investigated the expression of cyclin D1, the $G_{1}$ phase apoptosis gene product p53, a p53 downstream gene cyclin-dependent kinase inhibitor p21waf1/cip1, the apoptosis gene Bax and 
the proliferation-associated gene TGF- $\beta 1$. Following treatment with $0.1 \mu \mathrm{M}$ ED5, there were no significant differences in p53, p21, or Bax mRNA relative to controls. However, cyclin D1 and TGF- $\beta 1$ mRNA syntheses were significantly inhibited by ED5 treatment. Our findings are consistent with those of Fu et al. (16) using gene chip analysis of human vascular endothelial cells. Our results are also consistent with those of McCaffrey et al. (17) who performed a cDNA chip analysis on human carotid atherosclerotic plaques, and concluded that cyclin D1 is regulated by Egr-1. The cyclin D1 expression study reported here not only confirms the specific effect of ED5 on Egr-1, but also demonstrates that ED5 down-regulates cyclin D1 expression by inhibiting Egr-1 expression, resulting in cell cycle arrest at the $G_{0} / G_{1}$ phase, which therefore decreases the $S+G_{2} / M$ ratio and further inhibits VSMC proliferation.

Previous studies have suggested that the enhancement of TGF- $\beta 1$ activity is observed not only following stenosis lesions in animal models $(18,19)$ but also in human vessels (20). A study of blood vessels following rat balloon injury demonstrated that the elevated expression levels of TGF- $\beta 1$ could last for at least 2 weeks; importantly, administration of an antibody against TGF- $\beta 1$ inhibited neointimal formation $(21,22)$, suggesting that TGF- $\beta 1$ plays an essential role in restenosis. The present results demonstrate that 1) Egr-1 and TGF- $\beta 1$ have low expression levels under serum-free conditions, 2) expression of Egr-1 increases earlier than that of TGF- $\beta 1$ following stimulation with $10 \%$ serum, and 3) levels of TGF- $\beta 1$ decrease later than do Egr-1 levels following transfection with ED5. Taken together, these findings suggest that the expression and activation of TGF- $\beta 1$ are likely to be regulated by Egr-1. This theory is consistent with the finding that Egr-1 bound to the specific recognition region adjacent to the TGF- $\beta 1$ promoter, and induced TGF- $\beta 1$ expression (23). The TGF- $\beta 1$ promoter

\section{References}

1. Nobuyoshi M, Kimura T, Nosaka H, Mioka S, Ueno K, Yokoi $\mathrm{H}$, et al. Restenosis after successful percutaneous transluminal coronary angioplasty: serial angiographic follow-up of 229 patients. J Am Coll Cardiol 1988; 12: 616-623.

2. Holmes DR Jr, Vlietstra RE, Smith HC, Vetrovec GW, Kent $\mathrm{KM}$, Cowley MJ, et al. Restenosis after percutaneous transluminal coronary angioplasty (PTCA): a report from the PTCA Registry of the National Heart, Lung, and Blood Institute. Am J Cardiol 1984; 53: 77C-81C

3. Kent KM. Restenosis after percutaneous transluminal coronary angioplasty. Am J Cardiol 1988; 61: 67G-70G.

4. Sarkar R, Meinberg EG, Stanley JC, Gordon D, Webb RC. Nitric oxide reversibly inhibits the migration of cultured vascular smooth muscle cells. Circ Res 1996; 78: 225-230.

5. Santiago FS, Lowe HC, Kavurma MM, Chesterman CN, Baker A, Atkins DG, et al. New DNA enzyme targeting Egr1 mRNA inhibits vascular smooth muscle proliferation and regrowth after injury. Nat Med 1999; 5: 1264-1269. has two GC-rich Egr-1 binding sites; activated Egr-1 may directly interact with these sites and thereby regulate gene expression (24). In addition, TGF- $\beta 1$ expression itself may serve as a stimulus to activate Egr-1, forming a positive feedback loop with an amplified cascade effect (25). These results may explain why ED5 down-regulates TGF- $\beta 1$ and Egr-1 expression.

Nair et al. (26) reported that Egr-1 inhibits cancer cell growth and induces cell apoptosis by p53. However, Santiago et al. (5) found that the intimal hyperplasia triggered by Egr-1 is not a result of decreased cell apoptosis. Therefore, whether Egr-1 is related to cell apoptosis remains unclear. Our FACS results suggested that ED5 transfection had no effect on VSMC apoptosis or necrosis. In addition, transfection with ED5 did not result in any alterations in p53, p21, or Bax expression levels, suggesting that ED5 did not induce cell cycle arrest in the $\mathrm{G}_{0} / \mathrm{G}_{1}$ phase or VSMC apoptosis through a p53 or p21 pathway. These findings are consistent with those of Mnjoyan and colleagues (27) who demonstrated that serum-induced elevations of p53 have a negative-feedback regulatory effect on VSMC proliferation and division through regulation of p21 and Bax.

As a transcription factor, the protein product of the Egr1 gene, either independently or by complexing with other nucleoproteins, can directly regulate the expression of target genes and ultimately influence cell proliferation. Targeting Egr-1 expression may be a novel therapeutic strategy to treat atherogenesis and secondary intimal hyperplasia.

\section{Acknowledgments}

The grant support from the Chinese National Natural Science Foundation (\#30871074) is gratefully acknowledged.

6. Thiel G, Cibelli G. Regulation of life and death by the zinc finger transcription factor Egr-1. J Cell Physiol 2002; 193: 287-292.

7. Khachigian LM. Early growth response-1 in cardiovascular pathobiology. Circ Res 2006; 98: 186-191.

8. Takahashi Y, Fujioka Y, Takahashi T, Domoto K, Takahashi A, Taniguchi $\mathrm{T}$, et al. Chylomicron remnants regulate early growth response factor- 1 in vascular smooth muscle cells. Life Sci 2005; 77: 670-682.

9. Liu GN, Teng YX, Yan W. Transfected synthetic DNA enzyme gene specifically inhibits Egr-1 gene expression and reduces neointimal hyperplasia following balloon injury in rats. Int $J$ Cardiol 2008; 129: 118-124.

10. Curcio A, Torella D, Cuda G, Coppola C, Faniello MC, Achille $\mathrm{F}$, et al. Effect of stent coating alone on in vitro vascular smooth muscle cell proliferation and apoptosis. Am J Physiol Heart Circ Physiol 2004; 286: H902-H908.

11. Yasumoto H, Kim S, Zhan Y, Miyazaki H, Hoshiga M, Kaneda 
$\mathrm{Y}$, et al. Dominant negative c-jun gene transfer inhibits vascular smooth muscle cell proliferation and neointimal hyperplasia in rats. Gene Ther 2001; 8: 1682-1689.

12. Kume M, Komori K, Matsumoto T, Onohara T, Takeuchi K, Yonemitsu $Y$, et al. Administration of a decoy against the activator protein-1 binding site suppresses neointimal thickening in rabbit balloon-injured arteries. Circulation 2002; 105: 1226-1232.

13. Ohtani K, Egashira K, Usui M, Ishibashi M, Hiasa KI, Zhao Q, et al. Inhibition of neointimal hyperplasia after balloon injury by cis-element 'decoy' of early growth response gene-1 in hypercholesterolemic rabbits. Gene Ther 2004; 11: 126132.

14. Lowe HC, Fahmy RG, Kavurma MM, Baker A, Chesterman $\mathrm{CN}$, Khachigian LM. Catalytic oligodeoxynucleotides define a key regulatory role for early growth response factor- 1 in the porcine model of coronary in-stent restenosis. Circ Res 2001; 89: 670-677.

15. Santoro SW, Joyce GF. A general purpose RNA-cleaving DNA enzyme. Proc Natl Acad Sci U S A 1997; 94: 42624266.

16. Fu M, Zhu X, Zhang J, Liang J, Lin Y, Zhao L, et al. Egr-1 target genes in human endothelial cells identified by microarray analysis. Gene 2003; 315: 33-41.

17. McCaffrey TA, Fu C, Du B, Eksinar S, Kent KC, Bush H Jr, et al. High-level expression of Egr-1 and Egr-1-inducible genes in mouse and human atherosclerosis. $J$ Clin Invest 2000; 105: 653-662.

18. Chamberlain J, Gunn J, Francis SE, Holt CM, Arnold ND, Cumberland DC, et al. TGFbeta is active, and correlates with activators of TGFbeta, following porcine coronary angioplasty. Cardiovasc Res 2001; 50: 125-136.

19. Majesky MW, Lindner V, Twardzik DR, Schwartz SM, Reidy MA. Production of transforming growth factor beta 1 during repair of arterial injury. J Clin Invest 1991; 88: 904-910.

20. Nikol S, Isner JM, Pickering JG, Kearney M, Leclerc G, Weir L. Expression of transforming growth factor-beta 1 is increased in human vascular restenosis lesions. J Clin Invest 1992; 90: 1582-1592.

21. Wolf YG, Rasmussen LM, Ruoslahti E. Antibodies against transforming growth factor-beta 1 suppress intimal hyperplasia in a rat model. J Clin Invest 1994; 93: 1172-1178.

22. Smith JD, Bryant SR, Couper LL, Vary CP, Gotwals PJ, Koteliansky VE, et al. Soluble transforming growth factorbeta type II receptor inhibits negative remodeling, fibroblast transdifferentiation, and intimal lesion formation but not endothelial growth. Circ Res 1999; 84: 1212-1222.

23. Khachigian LM, Lindner V, Williams AJ, Collins T. Egr-1induced endothelial gene expression: a common theme in vascular injury. Science 1996; 271: 1427-1431.

24. Kim SJ, Park K, Rudkin BB, Dey BR, Sporn MB, Roberts AB. Nerve growth factor induces transcription of transforming growth factor-beta 1 through a specific promoter element in PC12 cells. J Biol Chem 1994; 269: 3739-3744.

25. Goetze S, Kintscher U, Kaneshiro K, Meehan WP, Collins A, Fleck E, et al. TNFalpha induces expression of transcription factors c-fos, Egr-1, and Ets-1 in vascular lesions through extracellular signal-regulated kinases $1 / 2$. Atherosclerosis 2001; 159: 93-101.

26. Nair P, Muthukkumar S, Sells SF, Han SS, Sukhatme VP, Rangnekar VM. Early growth response-1-dependent apoptosis is mediated by p53. J Biol Chem 1997; 272: 2013120138.

27. Mnjoyan ZH, Dutta R, Zhang D, Teng BB, Fujise K. Paradoxical upregulation of tumor suppressor protein p53 in serum-stimulated vascular smooth muscle cells: a novel negative-feedback regulatory mechanism. Circulation 2003; 108: $464-471$. 